\title{
Genetic parameters of some Egg Production traits in Japanese quail in a tropical Environment.
}

\author{
S. I. Daikwo, ${ }^{1}$ N. I. Dim $^{2}$ and O. M. Momoh ${ }^{2}$ \\ ${ }^{I}$ Department of Animal production and Health, Federal University Wukari, Taraba State Nigeria. \\ ${ }^{2}$ Department of Animal Breeding and Physiology, Federal University of Agriculture Makurdi, Benue State.
} Nigeria.

\begin{abstract}
A study was undertaken to evaluate the genetic parameters of some egg production traits in the Japanese quail. Two hundred and five quail hens were investigated for the traits under study. The mixed Model Least-squares and Maximum Likelihood Computer Programme of Harvey (1990) was applied to estimate heritability, genetic and phenotypic correlations of the egg production traits. The mean bodyweight at first egg was $145.68 \pm 0.74 g$. Mean age at first egg was $47.01 \pm 0.23$ days while the average number of eggs laid per quail hen per year was 248. The egg production traits studied had low to moderate heritabilities with high standard errors. Part-period egg number had high and positive genetic correlation with age at first egg, annual egg number and annual egg mass. It was concluded that the egg production traits studied could best be improved through crossbreeding and family selection methods, and selection for part-period egg number could possibly improve annual egg number and reduce generation interval.
\end{abstract}

Key words: Japanese quail, egg production, heritability, genetic correlation.

\section{Introduction}

Like the chicken, Japanese quails belong to the family phasianidae. In the wild, it is a small migratory bird originating from the Far East where the birds were first raised in bird cages in Japan and china around the $15^{\text {th }}$ century because of its singing ability, and later recognized in Japan as a good egg-laying bird for human consumption (Wakasugi, 1984). Female Japanese quails begin to lay eggs at the age of 6 weeks, and during the entire reproductive period lasting from 10 to 12 months, are able to lay about 300 eggs (Bronislawa et al., 2008).

Egg production is one of the major performance parameters of laying birds. Egg production in Japanese quail is influenced by additive genetic effects and several factors such as: age at sexual maturity, weight of the bird, nutrition, the system of management and the environment. Egg production can be reported as whole record performance (by monitoring the annual production) or part-record performance (short-term production). Whole record production can be predicted from part-record egg production through the use of mathematical models and projections of the egg production curve. If significant positive genetic correlation is found between part-period egg traits and annual egg traits, early selection can be undertaken using the part-period records. The objective of this study, therefore, was to evaluate the performance of Japanese quail in egg production traits and to estimate the genetic parameters thereof.

\section{Materials And Methods}

This research was carried out at the poultry unit of the Teaching and Research Farm of the Faculty of Agriculture, Kogi State University Anyigba, Nigeria. Anyigba lies between longitudes $5^{0} 15^{\prime}$ and $7^{0} 45^{1}$ North and Latitude $5^{0} 45^{1}$ and $8^{0} 45^{1}$ East with mean annual rainfall of $1,808 \mathrm{~mm}$. The natural day length for Anyigba is $12-13$ hours with average monthly temperature that varies from $17^{\circ} \mathrm{C}-36.2^{\circ} \mathrm{C}$. The relative humidity varies from an average of $65-85 \%$ throughout the year (Amhakian, 2009).

The foundation stock from which the birds used for the study were hatched consisted of 90 females and 30 males maintained in the farm as separate non-pedigreed, unselected and unimproved population. A mating ratio of 1:3 generated 684 day old chicks in three hatches. The full details of the mating, production, multiplication and management of the experimental quail chicks from hatching to 5 weeks of age have been described by Daikwo (2011).

After 5 weeks of age, 205 female quails were moved from the rearing pens and placed individually in $25 \mathrm{~cm} \times 25 \mathrm{~cm} \times 30 \mathrm{~cm}$ wooden wire mesh cages and monitored for annual egg production. While in egg production, the birds were fed formulated layers diet containing $18 \%$ crude protein and $2707 \mathrm{kcal} / \mathrm{kg}$ of feed as recommended by Dafwang(2006). Feed and water were provided ad libitum. Strict hygienic standard was maintained throughout the study period. Eggs were collected twice daily at $10.00 . \mathrm{am}$ and 5.00p.m and recorded on the egg chart. 
Traits Measured:

Age at first egg: The age in days of each quail was recorded when her first egg was laid.

Body weight at first egg: When the first egg was laid by a quail, her body weight in grammes was measured on that day.

Weight of first egg: When the first egg of each quail was laid, the weight in grammes was taken.

Part-period and Total period egg number: The annual egg production was divided into part-period (3 months) egg number and total period (annual or 12 months) egg number.

Egg weight: All eggs laid by each quail were weighed singly one day each week. The

Arithmetic mean of all the single weights was computed to form the mean weekly weight for each quail hen. The arithmetic average of all the single weights was computed to form the average part-period and total period egg weights.

Egg mass: This was calculated as the product of egg number and egg weight.

Statistical Analysis: Data were analyzed using SPSS 14.0 (2004). The following model was used in the analysis.

$Y_{i j}=\mu+B_{j}+e_{i j}$

Where $Y_{i j}$ is the individual hen observation, $\mu$ is the population mean, $B_{j}$ is the effect of hatch $(j=1, . .3)$, $e_{i j}$ is the residual random error.

Data were further subjected to genetic analysis using the Mixed Model Least-squares and Maximum Likelihood Computer Programme of Harvey (1990). The reduced sire model (Becker, 1992) was used to fit the data.

$$
Y_{i j}=\mu+a_{i}+e_{i j}
$$

Where $\mathrm{Yij}$ is the observation of the $\mathrm{j}^{\text {th }}$ progeny of the $\mathrm{i}^{\text {th }}$ sire, $\mu$ is the population mean, $\mathrm{a}_{i}$ is the random effect of the $i^{\text {th }}$ sire $(i=1, \ldots . .30)$

$\mathrm{e}_{\mathrm{ij}}=$ Residual random error. The Harvey programme computes estimates of genetic and phenotypic correlation as well as heritability of traits from sire variance components.

\section{Results And Discussion}

Table 1 shows the mean values of egg production traits in Japanese quail. The body weight at first egg, age at first egg, weight of first egg, part-period egg number, total egg number, part-period average egg weight, total average egg weight, part-period egg mass and total egg mass were $145.68 \pm 0.74 \mathrm{~g}, 47.01 \pm 0.23$ days, $7.12 \pm 0.06 \mathrm{~g}, \quad 72.19 \pm 0.22, \quad 247.64 \pm 0.93, \quad 8.19 \pm 0.04 \mathrm{~g}, \quad 8.17 \pm 0.04 \mathrm{~g}, \quad 590.88 \pm 3.64 \mathrm{~g}$ and $2024.10 \pm 12.60 \mathrm{~g}$, respectively. The body weight at first egg of $145.68 \pm 0.74 \mathrm{~g}$ obtained in this study is similar to $145.2 \mathrm{~g}$ reported by El-Ibiary et al. (1966) but lower than what Cerit (1997) and El-Deen et al. (2008) reported. The variation in this trait as observed in this study and those reported by these authors could be due to the fact that the population used for this study were not subjected to selection for body weight at first egg as those under reference, thus leading to high variability and low performance in body weight at first egg. The $7.12 \pm 0.06 \mathrm{~g}$ reported for weight of first egg in this study is lower than the value of 8.99-9.72 reported by El-Full (2001). The age at first egg reported in this study is in close agreement with the value of $45.82 \pm 0.22$ days reported by Sezer et al. (2006). El-Full (2001) and El-Deen et al. (2008) reported higher values of 61.22 and 50.94 days. Age at first egg can be highly variable because it is affected by feeding and management practices. Early age at first egg can be advantageous because selection for it could lead to reduced generation interval, but for commercial egg production it will lead to the production of many small eggs which may not find a ready market. However, if early age at first egg is accompanied by a corresponding increase in body weight then the egg size will also increase.

The total egg number of about 248 eggs reported in this study agrees fairly well with the value of 250 eggs reported by NVRI (1994). It is however lower than the 290eggs and 282egg reported by Sundaram (1989) and Cerit (1997), respectively. The differences in annual egg number could be attributed to managerial and climatic conditions prevailing at the various study locations. The average annual egg weight obtained in this study is lower than the $10.00-11.86 \mathrm{~g}$ reported by Abdel Tawab (2006). Differences in genetic make-up, management and environmental factors could be responsible for the variation in annual egg weight.

Heritability estimates from sire variance component of egg production traits of Japanese quail is presented in Table 2. The egg production traits studied had low to moderate heritabilities. The moderate heritability estimate $(0.31 \pm 0.08)$ of age at first egg reported in this study agrees with the findings of Farahat (1998) and El-Full (2001). The heritability of part-period egg number $(0.23 \pm 0.31)$ reported in this study is similar to that reported by Fair full and Gowe (1990) in chickens. The low to moderate heritabilities with high standard error estimates of egg production traits obtained in this study indicate that improvement in these egg production traits may not be rapid using mass selection procedures. 
Table 3 shows the genetic (below diagonal) and phenotypic (above diagonal) correlation among egg production traits in the Japanese quail. Part-period egg number had high positive genetic correlation with age at first egg, weight of first egg, total egg number and total egg mass. Part-period egg number had negative genetic correlation with average part-period and total egg weights. There were instances where genetic correlations between some egg production traits gave values that were outside parametric range. The phenotypic correlation between egg production traits ranged from -0.03 to 0.99 . Any improvement in part-period egg number could cause a corresponding improvement in annual egg number, egg mass and age at first egg because of the positive genetic correlation between them. However, improvement in part-period egg number could lead to a reduction in both part-period average egg weight and average annual egg weight due to the negative genetic correlation between them. The incentive to select for part-period egg number because of its high positive genetic correlation with annual egg number and age at first egg, both of which could lead to reduction in generation interval may lead to a compromised egg weight. This is because average annual egg weight had a negative genetic correlation with the annual egg number and age at first egg. The problem of sampling errors as well as small sample size data could have caused some genetic correlation estimates to go outside parametric range. The phenotypic correlation among the egg production traits followed the same pattern as the genetic correlation except that they were lower in values. Similar observations have been reported by Atkare and Khan (1998), and Momoh (2005).

\section{Conclusion}

The annual egg number of 248 eggs per quail hen is fairly high and can ensure reasonable supply of eggs to small households. The egg production traits in this study can be best improved through crossbreeding and family selection methods. Selection for part-period egg number would increase annual egg number and reduce generation interval in the Japanese quail. However, the advantages and disadvantage of such improvement option should be carefully considered because egg weight might be compromised.

\section{References}

[1]. Abdel-Tawab, S.K. (2006). The effect of selection for egg weight on some productive traits in Japanese quail. M.Sc. Thesis Fac. Agric. Al-Azhar Univ. Cairo, Egypt. 66pp.

[2]. Amhakhian, S. O. (2009). Evaluation of Phosphorus status of some soils in Kogi State Nigeria. Ph.D. Thesis, Edo State University, Ekpoma, Nigeria. 161pp.

[3]. AtKare, S. S. and Khan, A. G. (1998). Relationship between part egg production records, bodyweight and egg weight in IMW Strain of white leghorn breed. Indian J. Anim. Sci. 58:361-365.

[4]. Becker, W. A. (1992). Manual of Quantitative Genetics. $5^{\text {th }}$ Edition USA, Academic Enterprise, Pullman. 189pp.

[5]. Bronislawa, C. J., Anna, J., Ewa, L., Artur, K. and Irek, M. (2008). Semen collection from Japanese quail using a teaser female. Turk. J. Vet. Anim. Sci. 32(1):19-24.

[6]. Cerit, H. (1997). Genetic and phenotypic parameters of various traits in the Japanese quail. Ph.D Thesis., Dept. Animal Breeding and Husbandry, Univ. Istanbul, Turkey. 198pp.

[7]. Dafwang, I. I. (2006). Nutrient requirements and feeding regiment in quail production. A paper presented at the National Workshop on quail production for sustainable household protein intake. NAERLS, Ahmadu Bello University Zaira. Sept. 11-13. pp. 12-19.

[8]. Daikwo, I. S. (2011). Genetic studies on Japanese quail in a tropical environment. Ph.D Thesis Dept. Animal Breeding and physiology, University of Agriculture, Makurdi, Nigeria. 161pp.

[9]. El-Deen, M.B., El-Tahawy, W.S., Attia, Y.A. and Meky, M.A. (2008). Inheritance of age at sexual maturity and its relationship with some production traits of Japanese quails. Egypt. Poult. Sci. J. 28 (4): 1217-1232.

[10]. El-Full, E.A. (2001). Genetic analysis of hatched egg weight, body weight at different ages and reproductive performance with their relationships in Japanese quail. Egypt. Poult. Sci. J. 21(2): 291-304.

[11]. El-Ibiary, H.M., Godfrey, E.F. and Shaffner, C.C. (1966). Correlations between growth and reproductive traits in the Japanese quail. Poult. Sci. J. 45: 463-469.

[12]. Fair full, R. W. and Gowe, R.S. (1990). Genetics of egg production in chickens. In: Poultry breeding and genetics. (Ed. Crawford, R.D). Amsterdam, the Netherlands. Elsevier Science Publishers, BV. 705-759.

[13]. Farahat, G.S. (1998). Estimation of some genetic and phenotypic parameters

[14]. for growth and reproductive traits of Japanese quail. M.Sc Thesis, Fac. Agric. Fayoum, Univ. Egypt. 98 pp.

[15]. Harvey, W.R. (1990). Mixed Model Least-squares and Maximum Likelihood computer programme. Ohio State University Columbus (Mimeo).

[16]. Momoh, O.M. (2005). Genetic and phenotypic evaluation of the Nigerian heavy chicken ecotype and its crossbreds with the light ecotype. Ph.D Thesis, Dept. Animal Breeding and physiology, Univ. Agriculture Makurdi. 167pp.

[17]. NVRI (1994). Farmer training on quail production and health management. National Veterinary Research Institute, Vom, Nigeria. $44 \mathrm{pp}$.

[18]. Sezer, M., Berberoglu, E. and Ulutas, Z. (2006). Genetic association between sexual maturity and weekly live weights in layingtype Japanese quail. South African J. Anim. Sci. 36(2): 142-148.

[19]. SPSS (2004). Statistical package for social sciences. Release 14.0 for windows. IL 60611. Chicago.

[20]. Sundaram, T. S. T. (1989). Comparative egg production efficiency of chickens, ducks and quails. Poult. Int. 26:60.

[21]. Wakasugi, N. (1984). Japanese quail. In: Evolution of Domesticated animals (Ed: Mason, I. L). Longman Inc., Newyork. $319-321$. 
Table 1: Least-squares Means \pm SEM and Coefficient of Variation (CV) of some Egg production Traits in Japanese quail

\begin{tabular}{lll}
\hline Trait & Mean \pm S.E & CV (\%) \\
\hline Bodyweight at ${ }^{\text {st }}$ egg (g) & $145.68 \pm 0.74$ & 7.26 \\
Age at $1^{\text {st }}$ egg (days) & $47.01 \pm 0.23$ & 7.01 \\
Weight of 1 ${ }^{\text {st }}$ egg (g) & $7.12 \pm 0.06$ & 1.44 \\
Part-period (3 months) egg number & $72.19 \pm 0.22$ & 4.41 \\
Total (Annual) egg number & $247.64 \pm 0.73$ & 4.22 \\
Part-period (3 months) average egg weight (g) & $8.19 \pm 0.04$ & 7.21 \\
Total (Annual) Average egg weight (g) & $8.17 \pm 0.04$ & 7.46 \\
& & \\
Part-period (3 months) egg mass (g) & $590.88 \pm 3.64$ & 8.81 \\
Total (Annual) egg mass (g) & $2024.10 \pm 12.60$ & 8.88 \\
\end{tabular}

Table 2: Heritability Estimates of some Egg Production Traits from Sire Variance components in Japanese Quail.

\begin{tabular}{lc}
\hline Parameter & $\mathbf{h}^{\mathbf{2}}$ \\
\hline Age at $1^{\text {st }}$ egg & $0.31 \pm 0.08$ \\
Weight of $1^{\text {st }}$ egg & $0.04 \pm 0.17$ \\
Part-period (3 months) egg number & $0.23 \pm 0.31$ \\
Total (Annual) egg number & $0.34 \pm 0.41$ \\
Part period (3 months) average egg weight & $0.15 \pm 0.18$ \\
Total (Annual) average egg weight & $0.20 \pm 0.34$ \\
Part-Period (3 months) egg mass & $0.17 \pm 0.017$ \\
Total (Annual) egg mass & $0.26 \pm 0.03$ \\
\hline
\end{tabular}

Table 3: Genetic (below diagonal) and phenotypic (above diagonal) correlations among egg production traits in Japanese quail.

\begin{tabular}{lcccccccc} 
& AFE & WFE & PPEN & TEN & APPEW & ATEW & PPEM & TEM \\
\hline AFE & & $0.16^{*}$ & $0.32^{* * *}$ & $0.34^{* * *}$ & -0.03 & 0.03 & $-0.18^{* *}$ & $-0.19^{* *}$ \\
WFE & 0.82 & & 0.05 & 0.03 & $0.47^{* * *}$ & $0.46^{* * *}$ & $0.41^{* * *}$ & $0.40^{* * *}$ \\
PPEN & 0.71 & 0.78 & & $0.97^{* * *}$ & 0.11 & 0.10 & $0.59^{* * *}$ & $0.54^{* * *}$ \\
TEN & 0.95 & 0.61 & 0.91 & & 0.11 & 0.10 & $0.58^{* * *}$ & $0.56^{* * *}$ \\
APPEW & -0.85 & 0.48 & -0.68 & -0.68 & & $0.99^{* * *}$ & $0.56^{* * *}$ & $0.88^{* * *}$ \\
ATEW & -0.82 & 0.63 & -0.34 & -0.46 & 1.06 & & $085^{* * *}$ & $0.88^{* * *}$ \\
PPEM & 0.49 & 0.81 & 0.84 & 0.91 & 1.25 & 0.86 & & $0.99^{* * * *}$ \\
TEM & 0.65 & 0.58 & 0.63 & 0.81 & 0.80 & 0.69 & 0.73 & \\
\hline
\end{tabular}

$*=(\mathrm{P}<0.05) \quad * *=(\mathrm{P}<0.01) \quad * * *=(\mathrm{P}<0.001)$

AFE- Age at $1^{\text {st }}$ egg, WFE- Weight of $1^{\text {st }}$ egg, PPEN- Part-period egg number,

TEN- Total egg number, APPEW- Part-period average egg weight,

ATEW- Total average egg weight, PPEM- Part- period egg mass, TEM- Total egg mass. 